\title{
PERIZINAN LINGKUNGAN HIDUP DAN SANKSI PIDANA BAGI PEJABAT PEMBERI IZIN
}

\author{
Fachreza Akbar Hidayat \\ Ahmad Basuki \\ Fakultas Hukum Universitas Wijaya Kusuma Surabaya \\ e-mail:ahmadbasuki_uwks@yahoo.com
}

\begin{abstract}
ABSTRAK
Prosedur dan Persyaratan penerbitan izin lingkungan telah di atur dalam Undang-Undang Perlindungan dan Pengelolaan Lingkungan Hidup. Hal ini penting, karena akan memberikan gambaran kepada seseorang atau badan hukum apa saja yang harus dipenuhi apabila ingin mengajukan izin lingkungan. Dengan dijelaskannya prosedur dan persyaratan tersebut, maka pejabat yang berwenang telah diberi rambu-rambu dalam menerbitkan izin lingkungan.
\end{abstract}

Kata Kunci: prosedur, persyaratan, izin lingkungan.

\begin{abstract}
Procedures and Requirements for the issuance of an environmental permit has been regulated in Law-Law Protection and Environmental Management. This is important, because it will give an overview to the person or any legal entity that must be fulfilled if you want to submit an environmental permit. With the procedures and requirements are explained, the authorities had given the signs-signs in issuing permits.
\end{abstract}

Keywords: procedures, requirements, environmental permits.

\section{PENDAHULUAN}

Lingkungan hidup merupakan suatu elemen yang tidak dapat dipisahkan dari kehidupan manusia. Oleh karena itu, manusia itu sendiri diwajibkan untuk melindungi dan melestarikan fungsi lingkungannya, walaupun kita sendiri tahu bahwa tidak semua manusia mempunyai niat untuk melakukannya. Contoh kecilnya banyak juga orang-orang yang membuang sampah, atau bahkan limbah dari rumah tangga secara sembarangan.

Pencegahan terhadap kemerosotan kualitas lingkungan hidup dan sumber daya alam dimaksudkan agar lingkungan hidup dan sumber daya alam tetap terpelihara keberadaan dan kemampuannya untuk mendukung berlanjutnya pembangunan, setiap aktivitas pembangunan haruslah dilandasi oleh dasar-dasar pertimbangan pelestarian dan sumber daya alam tersebut (Harun M. Husein, 1992:1). Keinginan untuk mempengaruhi pengaruh negatif dan resiko pada tingkat yang mungkin atau Risk Assesment dan mengelola resikonya atau Risk Management melalui mekanisme dan sistem hukum lingkungan dalam apa yang disebut sebagai Analisis Mengenai
Dampak Lingkungan (selanjutnya disebut dengan AMDAL) (M. Daud Silalahi, 1995:1).

Masalah sentral yang menjadi pusat perhatian dunia internasional adalah masalah yang berhubungan erat dengan pembangunan dan dampaknya terhadap kualitas lingkungan hidup atau quality of life. Hal ini terlihat dari perkembangan kongres-kongres Perserikatan Bangsa-Bangsa (yang selanjutnya disingkat PBB) mengenai The Prevention of Crime and The Treatment of Offenders yang sering menyoroti bentuk-bentuk dimensi kejahatan terhadap pembangunan atau crime against development, kejahatan terhadap kesejahteraan sosial atau crime against social welfare, dan kejahatan terhadap kualitas lingkungan atau crime against the quality of life. Ketiga bentuk kejahatan tersebut saling berhubungan erat, karena memang tidak dapat dilepaskan keterkaitan problem pembangunan dengan masalah kesejahteraan masyarakat dan masalah lingkungan hidup. Hubungan erat tersebut terlihat dalam salah satu Laporan Kongres PBB ke-7 pada bulan September 1985 di Milan, Italia yang menyatakan bahwa kejahatan lingkungan atau 
ecological/environmental crime bersifat: 1. menganggu kualitas lingkungan hidup (impinged on the quality of life); 2. menganggu kesejahteraan material seluruh masyarakat (impinged on the material well - being of entire societies); dan 3. mempunyai pengaruh negative terhadap upaya pembangunan bangsa (had a negative impact on the development effort of nations) (Muladi dan Barda Nawawi Arief, 2010:182).

Mengingat hakikat dan dimensi pengaruh negatif yang sangat luas dari kejahatan lingkungan hidup itu, maka wajarlah apabila berbagai upaya dilakukan untuk menanggulanginya, antara lain melalui upaya penegakan hukum pidana. Upaya penanggulangan masalah lingkungan hidup dengan hukum pidana sesuai dengan Hasil Kongres PBB ke-8 tahun 1990 di Havana, Kuba. Dalam resolusi The Role of Criminal Law in The Protection of Nature and the Environment (Dokumen No. A/CONF.144/L.4 tanggal 3 September 1990) antara lain dinyatakan bahwa disamping tindakan-tindakan berdasarkan hukum administrasi dan pertanggungjawaban berdasarkan hukum perdata, juga perlu diambil tindakan-tindakan terhadap masalah lingkungan hidup berdasarkan hukum pidana. Oleh karena itu, negara-negara anggota PBB dihimbau untuk mengimplementasikan secara efektif sistem hukum nasional, termasuk hukum pidana.

Sebagai bentuk respon positif terhadap himbauan Resolusi No. A/CONF.144/L.4 tanggal 3 September 1990 tersebut, maka berbagai langkah progresif telah dilakukan oleh Pemerintah RI, dengan mengganti Undang-Undang Nomor 23 tahun 1997 tentang Pengelolaan Lingkungan Hidup (Lembaran Negara RI Tahun 1997 Nomor 68 Tambahan Lembaran Negara RI Nomor 3699), yang lazim disebut UUPLH dengan Undang-Undang Nomor 32 Tahun 2009 tentang Perlindungan dan Pengelolaan Lingkungan Hidup (Lembaran Negara RI Tahun 1009 Tahun 140, Tambahan Lembaran Negara RI Nomor 5059), selanjutnya disebut UUPPLH.

Salah satu asas Pengelolaan Lingkungan Hidup dalam UUUPLH yang sebelumya tidak dianut dalam UUPLH, yaitu asas tata kelola pemerintahan (Pasal 2 UUPPLH). Menurut penjelasan Pasal 2 huruf $\mathrm{m}$, bahwa yang dimaksud asas tata kelola pemerintahan yang baik adalah bahwa perlindungan dan pengelolaan lingkungan hidup dijiwai oleh prinsip partisipasi, transparansi, akuntabilitas, efisiensi, dan keadilan.

Sebagai perwujudan dari prinsip akuntabilitas dalam penyelenggaraan kegiatan perlindungan dan pengelolaan lingkungan oleh pejabat administratif, maka UUPPLH mengkriminalisasikan perbuatan pejabat administratif yang melanggar norma dan prosedur perizinan di bidang lingkungan. Hal ini tampak pada Pasal 111 dan Pasal 112 UUPPLH.

Pemanfaatan sanksi pidana pada Pasal 111 dan Pasal 112 UUPPLH harus dipahami dalam konteks fungsi hukum pidana sebagai ultimum remidium karena secara substansial isi norma yang mengatur tentang pengelolaan lingkungan mempunyai karakter administratif, khususnya yang menyangkut penggunaan wewenang pemerintah di bidang perizinan. Atas pertimbangan tersebut, mengalami kondisi untuk segera dikembangkan lebih lanjut ketentuan hukumnya sesuai dengan perkembangan baru, masalah-masalah yang belum terakomodasi oleh ketentuan-ketentuan yang dianggap mengandung kelemahan-kelemahan tertentu, seperti keterkaitan AMDAL dengan perizinan, mekanisme keterkaitan AMDAL dan masyarakat sebagai pelaksana peran serta rakyat dalam proses pengambilan keputusan, dan metode pengumpulan informasi yang mampu memberikan identifikasi terhadap berbagai pengaruh dan dampak lingkungan. Ini berarti dalam hal perencanaan proyek pusat, komisi daerah telah dilibatkan, yang akan menjamin keterpaduan vertikal.

Kurang dipahaminya proses AMDAL dalam sistem perizinan menyebabkan studi AMDAL seringkali dianggap memperlambat diperolehnya izin kegiatan. Oleh karena itu, penguasaan hukum yang mengatur dan menerbitkan masalah lingkungan dalam pembangunan wajib kita menguasai pula ilmuilmu lain yang relevan, misalnya ekonomi, sosial budaya, planologi, hidrologi, kimia dan biologi. Pendekatan interdisipliner ilmu demikian dapat dan berkembang. Meningkatkan kegiatan pembangunan, akan membawa perkembangan baru atas pengertian bahaya, kerugian dan lingkungan tercemar terhadap aspek kesehatan dan lingkungan salah satu Instrumen Hukum yang dikembangkan dan mengatasi ini adalah AMDAL. AMDAL sebagai studi ilmiah dianggap mempunyai kemampuan untuk melakukan prediksi dan identifikasi itu terhadap kemungkinan timbulnya dampak lingkungan. Oleh karena itu, AMDAL dalam proses pengambilan keputusan dianggap sebagai Significant Agency Expertise.

Dalam pengertian di atas, berarti aparat pemerintah (agency) dapat dikualifikasi dan mempunyai Primary Jurisdiction yang memberikan kedudukan hukum 
yang istimewa baginya untuk memutuskan apa yang menurut aparatur pemerintah paling menguntungkan berdasarkan keahliannya yang khusus, karena itu kedudukan ini memberikan dasar hukum yang kuat baginya untuk menetapkan pilihan yang terbaik dan bersifat final.

Menciptakan suatu pembangunan yang lebih berkesinambungan, faktor lingkungan hidup menjadi perhatian yang utama, sebab pada hakekatnya adalah, Gangguan terhadap keseimbangan lingkungan yaitu bahwa manusia sadar untuk mengubah keseimbangan lingkungan dari tingkat kualitas yang lebih tinggi. Dalam hal ini harus menjaga agar lingkungan tetap mampu untuk mendukung tingkat hidup pada kualitas yang lebih tinggi (Ninik Suparni, 1994:89). Oleh karena itu pembangunan yang memungkinkan timbulnya dampak penting terhadap lingkungan harus dibuat analisis mengenai dampak lingkungan. Kewajiban membuat analisis mengenai dampak lingkungan dapat kita lihat pada Pasal 22 Undang-Undang Nomor 32 Tahun 2009 tentang Perlindungan dan Pengelolaan Lingkungan Hidup yang menyatakan bahwa setiap usaha yang berdampak penting terhadap lingkungan hidup wajib memiliki AMDAL.

Melalui Peraturan Menteri Negara Lingkungan Hidup Nomor 11 Tahun 2009 tentang Persyaratan Kompetensi Dalam Penyusunan Dokumen Analisis Mengenai Dampak Lingkungan Hidup dan Persyaratan Lembaga Pelatihan Kompetensi Penyusun Dokumen Analisis Mengenai Dampak Lingkungan Hidup yang akan berlaku efektif pada tanggal 11 Nopember 2009, Kementerian Negara Lingkungan Hidup telah melakukan sertifikasi kompetensi nasional terhadap personil penyusun dokumen AMDAL dan registrasi kompetensi di bidang AMDAL terhadap Lembaga Jasa Penyedia Penyusunan Dokumen AMDAL dan Lembaga Pelatihan Kompetensi Penyusun Dokumen AMDAL. Tujuan dikembangkannya sistem ini adalah untuk menjamin mutu dokumen AMDAL, sehingga standar mutu dokumen AMDAL yang dihasilkan akan sama di seluruh Indonesia.

Sesuai dengan ketentuan Pasal 22 di atas maka pemerintah berhasil menetapkan Peraturan Pemerintah No. 27 Tahun 2012 tentang Izin Lingkungan. Peraturan Pemerintah ini merupakan tonggak sejarah yang amat penting dalam rangka pembangunan berwawasan lingkungan serta pembangunan berkelanjutan. Mengenai masalah AMDAL adalah menyangkut masalah generasi penerus, maka peranan pihak yang berkepentingan yaitu pemrakarsa, aparatur pemerintah, dan masyarakat sangat penting. Oleh karena itu untuk menegakkan analisis mengenai dampak lingkungan ini harus ada kerjasama yang baik antara aparatur pemerintah dan pihak yang terkait. Untuk itu Menteri Negara Kependudukan dan Lingkungan Hidup telah mengeluarkan beberapa keputusan sebagai realisasi dari pelaksanaan Peraturan Pemerintah Nomor 27 Tahun 2012 yang isinya merupakan pedoman bagi para konsultan yang akan membuat analisis mengenai dampak lingkungan.

Dalam membuat data, seorang pemrakarsa proyek harus mengetahui apakah proyek yang akan didirikannya itu wajib dilengkapi dengan analisis mengenai dampak lingkungan, jadi disini keadaan dari lokasi proyek harus jelas. Secara yuridis, analisis mengenai dampak lingkungan dibutuhkan hanya terhadap kegiatan pembangunan yang berdampak penting, mengenai ada atau tidaknya dampak penting itu tidak mudah diukur dengan barometer tertentu. Sebab formulasi hukum tidak secara jelas memberikan batas baik secara kuantitatif maupun kualitatif tentang apa yang merupakan dampak yang penting. Secara yuridis hanya menyatakan dampak penting itu berupa perubahan lingkungan yaitu yang sangat mendasar bersumber dari suatu kegiatan. Contoh dampak itu paling tidak menyangkut hidup orang banyak antara lain menyangkut alam, flora dan fauna, dan sebagainya yang dapat terganggu akibat langsung terhadap polusi udara, air, darat.

Sehubungan dengan hal tersebut di atas, maka terhadap usaha yang menimbulkan dampak penting, wajib dilengkapi dengan analisis mengenai dampak lingkungan. Oleh sebab itu bagi proyek yang mempunyai dampak penting banyak sekali yang meminta pembuatan analisis mengenai dampak lingkungan sehingga mendorong munculnya pihak-pihak yang memanfaatkan kesempatan dalam kesempitan, akibatnya studi analisis mengenai dampak lingkungan hanya formalitas saja, yang tidak dilaksanakan berdasarkan prosedur yang telah ditentukan oleh undang-undang.

Berdasarkan uraian di atas, maka akibat mengenai analisis mengenai dampak lingkungan dianggap formalitas saja, banyak sekali terdapat data fiktif yaitu data yang diperoleh dari hasil data konsultan saja atau bisa juga dari hasil pemikiran yang dibuat oleh konsultan itu dapat saja karena kesengajaan atau karena kelalaiannya sehingga data yang sebenarnya harus dicantumkan ke dalam analisi mengenai dampak 
lingkungan tidak dibuatnya secara tepat, akibatnya setelah terjadi dampak penting terhadap lingkungan maka diketahui segala kesalahannya. Peran pejabat sangat penting karena di tangan pejabat inilah keputusan bisa atau tidaknya izin ini harus dikeluarkan. Dalam perspektif KUHP, norma hukum yang memungkinkan untuk menjamin terlaksananya akuntabilitas pejabat dalam proses penerbitan izin dapat ditemukan dalam Pasal 423 KUHP yang menyatakan, seorang pejabat yang dengan maksud menguntungkan dirinya sendiri atau orang lain secara melawan hukum dengan menyalahgunakan kekuasaannya diancam dengan pidana penjara paling lama enam tahun.

Pemahaman tentang profesionalisme dan akuntabilitas pejabat penerbitan perizinan lingkungan dinilai penting, sehingga diibutuhkan pembahasan secara khusus mengenai prosedur penerbitan izin lingkungan dan apakah akibat hukum yang dapat dipertanggungjawabkan bagi pejabat yang tidak mengindahkan persyaratan dan prosedur dalam penerbitan izin.

\section{PEMBaHASAN}

\section{Pengertian dan Fungsi Perizinan}

Tidaklah mudah memberikan definisi apa yang dimaksud dengan izin, sukar memberikan definisi bukan berarti tidak terdapat definisi, bahkan ditemukan sejumlah definisi yang beragam. Menurut Sjahchran Basah, Izin adalah Perbuatan Hukum Administrasi Negara bersegi satu yang mengaplikasikan peraturan dalam hal konkret berdasarkan persyaratan dan prosedur sebagaimana ditetapkan oleh ketentuan peraturan perundang-undangan. Bilamana pembuat peraturan umumnya tidak melarang suatu perbuatan, tetapi masih juga memperkenankannya asal saja diadakan secara yang ditentukan untuk masing-masing hal konkret, maka keputusan Administrasi Negara yang memperkenankan perbuatan tersebut bersifat suatu izin (E. Utrecht, 1963:187). Izin merupakan suatu persetujuan dari pemerintah berdasarkan peraturan perundang-undangan yang berlaku untuk memperbolehkan melakukan tindakan atau perbuatan tertentu yang secara umum dilarang.

Menurut NM Spelt \& JBJM Ten Berger membagi menjadi dua yaitu: pertama, dalam arti luas, adalah suatu persetujuan dari penguasa berdasarkan peraturan Undang-Undang atau Peraturan Pemerintah untuk dalam keadaan tertentu menyimpang dari ketentuanketentuan larangan perundang-undangan; kedua, dalam arti sempit, pengikatan-pengikatan pada suatu peraturan izin. Pada umumnya didasarkan pada keinginan pembuat undang-undang untuk mencapai suatu tatanan tertentu atau untuk menghalangi keadaankeadaan yang buruk. Berdasarkan pada uraian tersebut, dapat disimpulkan bahwa yang dimaksud dengan izin adalah perbuatan pemerintah bersegi satu berdasarkan peraturan perundang-undangan untuk diterapkan pada peristiwa konkret menurut prosedur dan persyaratan tertentu.

Dilihat dari segi fungsi dan tujuannya izin merupakan instrumen yuridis yang digunakan oleh Pemerintah untuk mempengaruhi para warga agar mau mengikuti cara yang dianjurkannya guna mencapai suatu tujuan konket (H.R. Ridwan, 2007: 217). Mengenai tujuan perizinan, hal ini tergantung pada kenyataan konkret yang dihadapinya. Keragaman peristiwa konkret menyebabkan keragaman pula dari tujuan izin itu, yang secara umum dapat disebutkan sebagai berikut: 1. Keinginan mengarahkan; 2. Izin mencegah bahaya bagi lingkungan; 3. Keinginan untuk melindungi Obyek-obyek tertentu; 3. Izin hendak membagi benda-benda yang sedikit; 4. Izin memberikan pengarahan, dengan menyeleksi orangorang dan aktivitas-aktivitas, setelah memenuhi persyaratan-persyaratan tertentu (H.R. Ridwan, 2007:218).

\section{Tinjauan Umum tentang AMDAL}

AMDAL merupakan kajian dampak besar dan penting terhadap lingkungan hidup, dibuat pada tahap perencanaan, dan digunakan untuk pengambilan keputusan, hal-hal yang dikaji dalam proses AMDAL: aspek fisik-kimia, ekologi, sosial-ekonomi, sosialbudaya, dan kesehatan masyarakat sebagai pelengkap studi kelayakan suatu rencana usaha dan/atau kegiatan (Fandeli, 2004:154).

Secara yuridis bagaimana proses dan persyaratan penyusunan AMDAL telah diatur dalam Peraturan Pemerintah Nomor 27 Tahun 2012 tentang Izin Lingkungan (yang selanjutnya disebut PP No. 27 Tahun 2012). Peraturan Pemerintah ini diundangkan dalam Lembaran Negara Republik Indonesia Tahun 2012 Nomor 48 dan Tambahan Lembaran Negara Tahun 2012 Nomor 5285. PP No. 27 Tahun 2012 disusun sebagai pelaksanaan ketentuan dalam UndangUndang 32 Tahun 2009 tentang Perlindungan dan Pengelolaan Lingkungan Hidup (yang selanjutnya disebut UU No. 32 Tahun 2009), khususnya ketentuan 
dalam Pasal 33 dan Pasal 41. PP No. 27 Tahun 2012 mengatur dua instrumen perlindungan dan pengelolaan lingkungan hidup, yaitu instrumen kajian lingkungan hidup (dalam bentuk AMDAL dan UKL-UPL) serta instrumen Izin Lingkungan. Penggabungan substansi tentang AMDAL dan izin lingkungan dalam PP No. 27 Tahun 2012 ini dilakukan dengan pertimbangan bahwa AMDAL/UKL-UPL dan izin lingkungan merupakan satu kesatuan.

Dalam PP No. 27 Tahun 2012 mengatur suatu hubungan (interface) antara izin lingkungan dengan proses pengawasan dan penegakan hukum. Pasal 71 dalam PP No. 27 Tahun 2012 memberikan ruang yang jelas mengenai pengenaan sanksi atas pemegang izin lingkungan yang melanggar kewajibannya sebagaimana yang diatur dalam Pasal 53. Secara umum, dapat disimpulkan bahwa sasaran dari terbitnya PP No. 27 Tahun 2012 ini adalah terlindungi dan terkelolanya lingkungan hidup sedangkan sasaran mikro dari terbitnya peraturan ini adalah memberi dasar hukum yang jelas atas penerapan instrumen izin lingkungan dan memberikan beberapa perbaikan atas penerapan instrumen amdal dan UKL-UPL (kajian lingkungan hidup) di Indonesia.

\section{Prosedur dan Persyaratan Penerbitan Izin Lingkungan menurut UUPPLH}

Izin lingkungan hidup sebagai instrumen bagi pemerintah untuk mengendalikan aktivitas pengelolaan lingkungan hidup. Tujuannya agar lingkungan hidup tidak rusak, untuk kepentingan generasi sekarang dan generasi yang akan datang. Bahkan dalam UUD 1945 dinyatakan bahwa, warga negara berhak atas lingkungan hidup yang baik dan sehat.

Perizinan memberikan pengendalian terhadap kelestarian lingkungan hidup, meskipun tidak tertutup kemungkinan dalam pelaksanaannya bersinggungan dengan hak-hak masyarakat dalam berusaha maupun dalam mendapatkan haknya atas lingkungan hidup yang baik dan sehat. Mengenai komitmen pemerintah untuk memberikan perlindungan kepada hak-hak asasi manusia atas lingkungan hidup dapat ditemukan pada Pasal 28H ayat (1) UUD 1945, yakni setiap orang berhak hidup sejahtera lahir dan batin, bertempat tinggal, dan mendapatkan lingkungan hidup yang baik dan sehat serta memperoleh pelayanan kesehatan.

Dalam UUPPLH, izin merupakan instrumen dalam pengendalian perlindungan dan pengelolaan lingkungan hidup di Indonesia. Sebagai instrumen pengendalian, izin lingkungan hidup dapat menentukan berhasil tidaknya pelestarian fungsi lingkungan hidup untuk kelangsungan hidup manusia dan ekosistemnya.

UUPPLH mengatur tentang prosedur dan persyaratan izin lingkungan. Persyaratan izin lingkungan diatur dalam Pasal 22 UUPPLH. Dimana syaratnya harus memiliki AMDAL, yang kemudian disusun menjadi dokumen AMDAL. Dokumen AMDAL harus memuat antara lain: 1. Pengkajian mengenai dampak rencana usaha dan/atau kegiatan; 2. Evaluasi kegiatan disekitar lokasi rencana usaha dan/atau kegiatan; 3 . Saran masukan serta tanggapan masyarakat terhadap rencana usaha dan/atau kegiatan; 4. Prakiraan terhadap besaran dampak serta sifat penting dampak yang terjadi jika rencana usaha dan/atau kegiatan tersebut dilaksanakan; 5. Evaluasi secara holistik terhadap dampak yang terjadi untuk menentukan kelayakan atau ketidaklayakan lingkungan hidup; dan 6. Rencana pengelolaan dan pemantauan lingkungan hidup.

Prosedur Permohonan sampai diterbitkannya izin lingkungan diatur dalam Pasal 36 UUPPLH yang menjelaskan bahwa setiap usaha dan/atau kegiatan yang wajib memiliki AMDAL atau UKL-UPL wajib memiliki izin lingkungan. Lalu izin lingkungan tersebut diterbitkan berdasarkan keputusan kelayakan lingkungan hidup atau rekomendasi UKL-UPL. Selanjutnya, izin lingkungan tersebut wajib mencantumkan persyaratan yang dimuat dalam keputusan kelayakan lingkungan hidup atau rekomendasi UKL-UPL. Kemudian, izin tersebut diterbitkan oleh Menteri, gubernur, atau Bupati/Walikota sesuai dengan kewenangannya. Kemudian hal yang penting lagi untuk dikemukakan adalah menyangkut persyaratan izin usaha dan/atau kegiatan sebagaimana yang ditegaskan dalam Pasal 40 ayat (1) UUPPLH. Pemahaman secara acontrario terhadap Pasal 40 ayat (1) UUPPLH tersebut berarti Menteri, Gubernur, atau Bupati/Walikota tidak boleh menerbitkan izin usaha dan/atau kegiatan tanpa dilengkapi izin lingkungan.

Dalam Pasal 37 ayat (2) UUPPLH ditentukan juga, izin lingkungan dapat dibatalkan apabila: 1 . Persyaratan yang diajukan dalam permohonan izin mengandung cacat hukum, kekeliruan, penyalahgunaan, serta ketidakbenaran dokumen; 2. Penerbitannya tanpa memenuhi syarat sebagaimana tercantum dalam keputusan komisi tentang kelayakan lingkungan hidup atau rekomendasi UKL-UPL; atau 3. Kewajiban yang ditetapkan dalam dokumen AMDAL atau UKL-UPL tidak dilaksanakan oleh penanggungjawab usaha. 
Selanjutnya pasal 38 UUPPLH menentukan, izin lingkungan juga dapat di batalkan melalui keputusan (sesuai dengan UU No. 5 Tahun 1986 tentang Peradilan Tata Usaha Negara jo UU No. 9 Tahun 2004 tentang Perubahan UU No. 5 Tahun 1986 sebenarnya "putusan" bukan keputusan). Ketentuan yang juga penting mengenai perizinan bidang lingkungan hidup dalam Pasal 123 UUPPLH, yakni segala izin di bidang pengelolaan lingkungan hidup yang telah dikeluarkan oleh Menteri, Gubernur, atau Bupati/Walikota sesuai dengan kewenangannya wajib diintegrasikan ke dalam izin lingkungan paling lama 1 (satu) tahun sejak undang-undang ini ditetapkan.

Berdasarkan uraian tersebut, dapat disimpulkan bahwa sistem perizinan bidang lingkungan dalam UUPPLH adalah izin lingkungan dan izin usaha dan/ atau kegiatan pengelolaan lingkungan hidup. Kedua jenis izin tersebut merupakan instrumen pencegahan pencemaran dan/atau kerusakan lingkungan hidup dalam rangka pengendalian dan pengelolaan lingkungan hidup. AMDAL atau UKL-UPL merupakan persyaratan untuk memperoleh kedua izin tersebut. Karena terkait dengan AMDAL, UKL-UPL, usaha dan/atau kegiatan pengelolaan lingkungan hidup, izin lingkungan hidup juga harus memperhatikan ketentuan Pasal 14 UUPPLH, yakni beberapa instrumen pencegahan dan pencemaran dan/atau kerusakan lingkungan. Instrumen-instrumen yang dimaksud adalah Kajian Lingkungan Hidup Strategis (KLHS), tata ruang, Baku Mutu Lingkungan Hidup, AMDAL, UKL-UPL, instrumen ekonomi lingkungan hidup, dan peraturan perundang-undangan yang berbasis lingkungan hidup. Izin lingkungan hidup juga harus didasarkan pada Rencana Perlindungan dan Pengelolaan Lingkungan Hidup (Pasal 9 UUPPLH). Jika demikian, sistem perizinan lingkungan hidup haruslah terpadu, karena instrumen-instrumen pencegahan pencemaran dan/atau kerusakan lingkungan hidup di atas sesungguhnya tidak terpisahkan.

Berdasarkan uraian tersebut, terdapat beberapa ketentuan dalam UUPPLH yang tidak ada pada Undang-Undang Lingkungan yang sebelumnya, yaitu pertama, adanya Rencana Perlindungan dan Pengelolaan Lingkungan Hidup (RPPLH) yang harus dibuat dan dilaksanakan oleh Pemerintah dan Pemerintah Daerah. Kedua, adanya Kajian Lingkungan Hidup Strategis (KLHS) yang merupakan instrumen untuk memastikan diwujudkannya prinsip-prinsip pembangunan berkelanjutan. Ketiga, keharusan dalam pembentukan peraturan perundang-undangan berbasis lingkungan hidup. Keempat, keterkaitan antara izin lingkungan dengan izin usaha kegiatan. Kelima, adanya instrumen ekonomi lingkungan hidup untuk melestarikan fungsi lingkungan hidup. Keenam, anggaran berbasis lingkungan hidup. Ketujuh, pengaturan yang rinci mengenai kewenangan pemerintah dan dan pemerintah daerah dalam rangka perlindungan serta pengelolaan lingkungan hidup.

\section{Tindakan Mal Administrasi Pejabat dalam Penerbitan Izin Lingkungan}

Mal administrasi pejabat adalah suatu praktek yang menyimpang dari etika administrasi, atau suatu praktek administrasi yang menjauhkan dari pencapaian tujuan administrasi. Selama ini banyak kalangan yang terjebak memahami mal administrasi semata-mata sebagai penyimpangan administrasi dalam arti sempit, yaitu penyimpangan yang hanya berkaitan dengan ketatabukuan dan tulis menulis. Bentukbentuk penyimpangan diluar hal-hal yang bersifat ketatabukuan tidak dianggap sebagai perbuatan mal administrasi. Padahal terminologi mal administrasi dipahami lebih luas dari sekadar penyimpangan yang bersifat ketatabukuan sebagaimana selama ini dipahami banyak orang (Kupita Weda, 2007:1).

Menurut Pasal 1 angka 3 Undang-Undang Nomor 5 Tahun 1986, Pejabat Tata Usaha Negara (selanjutnya disebut pejabat) adalah seseorang yang berdasarkan peraturan perundang-undangan berwenang untuk mengambil keputusan di bidangnya dalam rangka melaksanakan salah satu kegiatan Tata Usaha Negara.

Selanjutnya, untuk mengontrol pelaksanaan wewenang pejabat yang telah diberikan oleh peraturan perundang-undangan tersebut, secara yuridis disediakan beberapa instrumen hukum untuk memeriksa dan mengadilinya, yaitu jalur Peradilan Tata Usaha Negara, apabila pokok perkaranya menyangkut pengujian keabsahan Keputusan Tata Usaha Negara yang selanjutnya disebut KTUN, dan jalur peradilan umum, apabila pokok perkaranya menyangkut di luar KTUN, baik yang bersifat perdata maupun pidana.

Salah satu aspek yang memungkinkan adanya pertanggungjawaban pidana pejabat (Philipus M. Hadjon, 2011:20) dalam melaksanakan tugas dan fungsinya mengandung unsur mal administratif. Secara etimologis mal administratif berasal dari bahasa latin, $\mathrm{mal}$ berarti jelek, jahat, dan administrare artinya melayani. 
Dengan demikian mal administratif mengandung arti pelayanan yang jelek atau buruk. Laporan tahunan 1997 Ombudsman Eropa menjelaskan, bahwa mal administration occurs when a public body fail to act in accordance with the rule or principle which is binding upon it. Secara lebih konkret E.I. Sykes et.al., dalam bukunya General Principles of Administratief Law, 1989 menjelaskan bahwa ... mal administration, a term which has been described as including bias, neglect, delay, inattention, incompetence, inaptitude, perversity, turpitude, and upbitrarines.

Sejalan dengan ketiga pengertian mal administrasi di atas, Pasal 1 butir 3 Undang-Undang Nomor 37 Tahun 2008 tentang Ombudsman Republik Indonesia menjelaskan bahwa, mal administrasi adalah perilaku atau perbuatan melanggar hukum, melampaui wewenang, menggunakan wewenang untuk tujuan lain dari yang menjadi tujuan wewenang tersebut, termasuk kelalaian atau pengabaian kewajiban hukum dalam penyelenggaraan pelayanan publik yang dilakukan oleh penyelenggara Negara dan Pemerintahan yang menimbulkan kerugian materiil dan/atau inmateriil bagi masyarakat dan orang perseorangan.

Selanjutnya, untuk menentukan suatu tindakan aparat atau pejabat publik bersifat mal-admisitratif atau tidak menurut Philipus M. Hardjon dapat diukur berdasarkan 3 (tiga) parameter, yaitu 1. peraturan perundang-undangan, 2 . asas-asas umum pemerintahan yang baik, atau 3. code of good administrative behavior.

Dengan pengertian dasar tersebut, mal administrasi dikaitkan dengan perilaku dalam pelayanan, khususnya yang dilakukan oleh pejabat publik. Dikaitkan dengan norma hukum administrasi, mal administrasi termasuk kategori norma perilaku aparat dalam pelayanan publik. Dalam posisinya sebagai norma perilaku aparat, maka setiap tindakan mal administrasi mengandung resiko atau konsekuensi terhadap pertanggungjawaban pribadi (faute de personale) yang bersifat administratif, perdata, maupun pidana.

Sesuai dengan pengertian, sifat, dan parameter mal administrasi sebagaimana telah dikemukakan di atas, dapat disimpulkan adanya 4 (empat) macam tindakan mal administrasi yang berimpilkasi terhadap pertanggungjawaban pidana pejabat, yaitu: pertama, pelanggaran terhadap prosedur penerbitan izin lingkungan sebagaimana dimaksud dalam Pasal 37 ayat (1) UUPPLH; Kedua, pelanggaran terhadap prosedur penerbitan izin usaha dan/atau kegiatan, sebagaimana diatur dalam Pasal 40 ayat (1) UUPPLH; Ketiga, pelanggaran yang berupa pengabaian atau kelalaian terhadap kewajiban hukum untuk melakukan pengawasan terhadap ketaatan penanggungjawab usaha dan/atau kegiatan terhadap persyaratan izin usaha dan/ atau kegiatannya, sebagaimana dimaksud dalam Pasal 71 ayat (1) UUPPLH; dan Keempat, pelanggaran yang berupa pengabaian atau kelalaian terhadap kewajiban hukum untuk melakukan pengawasan terhadap ketaatan penanggungjawab usaha dan/atau kegiatan terhadap persyaratan izin lingkungannya, sesuai dengan Pasal 72 ayat (1) UUPPLH.

\section{Pertanggungjawaban Pidana Pejabat dalam Penerbitan Izin Lingkungan}

Sebagaimana yang telah dikemukakan sebelumnya, bahwa tindakan mal administrasi pejabat menimbulkan cacat yuridis, sehingga melahirkan implikasi terhadap berbagai pertanggungjawaban hukum terhadap pejabat yang bersangkutan, baik secara administrasi, pidana, maupun perdata.

Hukum Pidana mensyaratkan adanya 3 (tiga) hal dalam rangka pertanggungjawaban pidana (criminal responsibility), yang secara konsepsional oleh Sauer disebut sebagai Trias dalam Hukum Pidana. Ketiga persoalan tersebut adalah: tindak pidana, pertanggungjawaban pidana, dan pidana (Sudarto, 1990:86). Dalam istilah yang lainnya, Barda Nawawi Arief menyebut sebagai 3 (tiga) persoalan dasar dalam hukum pidana, yaitu: konsep Perbuatan (P), konsep Orang (O), dan konsep Pidana (P), yang disingkat POP.

Sesuai dengan taksonomi yang dikemukakan Sauer dan Barda Nawawi Arief, sistematika pembahasan pertanggungjawaban pidana pejabat dalam kaitannya dengan mal administrasi dalam penerbitan izin di bidang lingkungan akan dilakukan.

Pertama, Klasifikasi dan Rumusan Tindak Pidana. Sebagaimana telah di kemukakan sebelumnya, bahwa terdapat 4 (empat) macam tindakan mal administrasi, mempunyai implikasi terhadap pertanggungjawaban pidana pejabat, yaitu pelanggaran terhadap prosedur dan persyaratan penerbitan izin. Jenis pelanggaran ini dapat dibedakan menjadi 2 (dua) macam yaitu: pelanggaran terhadap prosedur dan persyaratan penerbitan izin lingkungan. Ketentuan yang mengatur jenis pelanggaran ini adalah Pasal 111 ayat (1). Berdasarkan formulasi Pasal 111 ayat (1) tersebut dapat diidentifikasi adanya 2 unsur utama (bestand 
delen) dari tindak pidananya, yaitu menerbitkan izin lingkungan. dan tanpa dilengkapi dengan AMDAL, atau UKL-UPL sebagaimana dimaksud Pasal 37 ayat (1) UUPPLH.

2. Pelanggaran berupa pengabaian terhadap kewajiban hukum untuk melakukan pengawasan. Selanjutnya, jenis pelanggaran kedua yaitu pelanggaran terhadap prosedur dan persyaratan penerbitan izin usaha dan/atau kegiatan. Ketentuan yang mengatur jenis pelanggaran ini adalah Pasal 111 ayat (2). Berdasarkan formulasi Pasal 111 ayat (2) tersebut dapat dikemukakan adanya 2 (dua) unsur utama dari tindak pidananya, yaitu menerbitkan izin usaha dan/atau kegiatan, dan tanpa dilengkapi dengan izin lingkungan, seperti yang dimaksud dalam Pasal 40 ayat (1) UUPPLH.

Ada 2 (dua) macam pengawasan yaitu: a. pengawasan atas ketaatan penanggungjawab usaha dan/ atau kegiatan terhadap persyaratan izin lingkungannya. Larangan terhadap pengabaian terhadap pengawasan jenis ini diatur dalam Pasal 112 jo Pasal 72 UUPPLH. Berdasarkan rumusan Pasal 112 jo Pasal 72, maka dapat disimpulkan bahwa unsur utama dari tindak pidana tersebut adalah dengan sengaja, dan tidak melakukan pengawasan terhadap ketaatan penanggungjawab usaha dan/atau kegiatan atas peraturan perundangan dan izin lingkungan, serta mengakibatkan terjadinya pencemaran dan/atau perusakan lingkungan sehingga menyebabkan hilangnya nyawa manusia; $b$. yaitu pengawasan terhadap ketaatan penanggungjawab usaha dan/atau kegiatan atas ketentuan dalam peraturan perundang-undangan di bidang lingkungan. Larangan tersebut diatur dalam Pasal 112 jo Pasal 71 UUPPLH. Pasal 71, maka dapat disimpulkan bahwa unsur utama dari tindak pidana tersebut adalah dengan sengaja, tidak melakukan pengawasan terhadap ketaatan penanggungjawab usaha dan/atau kegiatan atas peraturan perundangan di bidang perlindungan dan pengelolaan lingkungan, serta mengakibatkan terjadinya pencemaran dan/atau perusakan lingkungan sehingga menyebabkan hilangnya nyawa manusia.

Kedua, Subyek yang dapat dipertanggungjawabkan. Memperhatikan bunyi Pasal 111 dan Pasal 112 UUPPLH, maka terlihat sekali bahwa adressat norma dari pasal tersebut adalah ditujukan kepada pejabat yang berwenang mengeluarkan izin (baik izin lingkungan maupun izin usaha dan/atau kegiatan) serta melakukan pengawasan terhadap ketaatan atas persyaratan perizinan maupun peraturan perundang- undangan. Adapun pejabat yang diberi wewenang untuk itu, secara atributif Pasal 37 ayat (1), Pasal 71 ayat (1) maupun Pasal 72 memberikan kewenangan kepada Menteri, Gubernur, atau Walikota/Bupati. Ini berarti, bahwa yang harus bertanggungjawab secara pidana terhadap setiap bentuk pelanggaran atau penyimpangan yang bersifat mal administrasi dalam kaitannya dengan penerbitan izin dan peraturan perundangan adalah Menteri, Gubernur, atau Bupati/ Walikota sesuai dengan porsi dan lingkup kewenangan masing-masing.

Prinsip pertanggungjawaban secara pidana sebagaimana yang telah dinyatakan di atas tidak berlaku, dalam hal pejabat itu mendelegasikan kewenangannya dalam hal pengawasan kepada aparat atau pejabat teknis di bidang perlindungan dan pengelolaan lingkungan hidup. Hal ini dimungkinkan sebagaimana tertera dalam Pasal 71 ayat (2) UUPPLH.

Ketiga, Pertanggungjawaban pidana. Pembicaraan tentang pertanggungjawaban pidana, tidak dapat dilepaskan dari pembahasan tentang tindak pidana. Demikian pula sebaliknya, tidak akan terjadi pemidanaan terhadap pelaku tindak pidana, kalau aspek pertanggungjawaban pidana pelaku tidak terpenuhi. Artinya, dalam rangka pemidanaan konsep tindak pidana dan konsep pertanggungjawaban pidana adalah dua anasir yang terpisah (dualism) ibarat dua sisi mata uang, terpisah tetapi berifat komplementer (Sudarto, 1990:45)

Seseorang tidaklah cukup alasan untuk di pidana apabila orang itu telah melakukan perbuatan yang telah bertentangan dengan hukum atau bersifat melawan hukum. Jadi, meskipun perbuatannya telah memenuhi rumusan delik dalam undang-undang dan tidak dibenarkan (an objective breach of a penal provision), namun hal tersebut belum memenuhi syarat untuk adanya penjatuhan pidana. Untuk penjatuhan pidana masih diperlukan adanya syarat bahwa orang yang melakukan perbuatan itu mempunyai kesalahan atau bersalah (subjective guilt). Dengan perkataan lain, orang tersebut harus dapat dipertanggungjawabkan atas pebuatannya, atau jika dilihat dari sudut perbuataannya, perbuataannya harus dipertanggungkan kepada orang tersebut. Dalam konteks inilah berlaku adegium tiada pidana tanpa kesalahan (Keine Strafe ohne Schuld atau Geen Straf ZonderSchuld atau Nulla Poena Sine Culpa), yang juga disebut ajaran culpabilitas.

Secara konsepsional, kesalahan mengandung beberapa unsur yang terkait, yaitu adanya kemampuan 
bertanggungjawab dalam diri si pembuat (schuldfahigkeit), artinya keadaan jiwa si pembuat harus normal, dan adanya hubungan batin antara si pembuat dengan perbuataan yang dilakukannya (baik yang berupa kesengajaan atau kealpaan), serta tidak adanya alasan penghapus kesalahan, atau alasan pemaaf. Dalam hal ketiga unsur tersebut terpenuhi, maka orang yang bersangkutan bisa dinyatakan bersalah atau mempunyai pertanggungjawaban pidana, sehingga bisa dijatuhi pidana.

Pengertian dan pemahaman tentang pertanggungjawaban memotret perumusan unsur kesalahan yang dilukiskan dalam Pasal 111 dan Pasal 112 dapat dikemukakan bahwa Pasal 111 tidak merumuskan secara ekplisit (tegas/tertulis) unsur kesalahannya (kesengajaan atau kealpaan), sehingga secara teoritis menimbulkan konsekuensi teknis yuridis dalam proses pembuktian di pengadilan, maksudnya Penuntut Umum tidak mempunyai keharusan untuk membuktikan unsur kesalahan pelaku (bersifat fakultatif); dan sebaliknya Pasal 112 merumuskan unsur kesalahan secara tegas, terbaca (eksplisit), yaitu dengan kalimat “... dengan sengaja".

Perumusan unsur kesalahan dalam bentuk kesengajaan tersebut menunjukkan dianutnya prinsip liability based on fault (pertanggungjawaban berdasarkan kesalahan atau asas culpabilitas) (Achmad Basuki, 2011:257). Bertolak dari asas culpabilitas ini, maka dalam pertanggungjawabannya tidak dapat diberlakukan tanggungjawab seketika (strick responsibility). Artinya secara teknis yuridis, Penuntut Umum mepunyai kewajiban untuk dapat membuktikan unsur kesalahan pelaku di dalam proses pemeriksaan di Pengadilan, sebab dalam hal ini unsur kesengajaan sebagaimana dimaksud merupakan unsur utama delik (bestand deel). Tidak terbuktinya unsur ini bisa mengakibatkan tidak dapat dipersalahkannya pelaku.

Keempat, Sanksi Pidana. Berdasarkan perumusan sanksi pidana yang diatur dalam Pasal 111 dan Pasal 112, maka dikemukakan sebagai berikut: 1. Bahwa ditinjau dari jenis sanksi pidana (strafsoort), Pasal 111 merumuskan adanya 2 (dua) macam sanksi pidana, yaitu pidana penjara dan pidana denda. Namaun demikian kalau dicermati secara seksama, bahwa kedua jenis sanksi tersebut dirumuskan dengan kata-kata "... dengan pidana penjara ... dan pidana denda ....", hal satu sanksi yang ditawarkan kepada hakim yaitu pidana penjara dan pidana denda secara bersamaan (komulatif). Berbeda dengan yang dianut dalam Pasal 112 yang merumuskan sanksinya dengan kata-kata "... dengan pidana penjara atau pidana denda ....", hal ini menunjukkan bahwa undang-undang memberikan kebebasan bagi Hakim untuk memilih salah satu dari 2 (dua) macam sanksi yang ditawarkan oleh undang-undang yaitu, pidana penjara atau pidana denda (alternative); 2. Jika dilihat dari segi beratringannya sanksi pidana (strafmaat), rumusan Pasal 111 maupun Pasal 112 dapat diketahui, bahwa kedua pasal menganut perumusan sanksi pidana maksimal, artinya hakim diberikan kebebasan untuk menakar berat-ringannya pidana yang dapat dijatuhkan sesuai dengan kesalahan pelaku asalkan tidak melampaui batas maksimal yang telah ditetapkan oleh Pasal 111 dan Pasal 112 UUPPLH; 3. Apabila dibandingkan antara sanksi pidana yang diatur dalam Pasal 111 dan Pasal 112 UUPPLH, maka dapat diketahui bahwa sanksi pidana yang diancamkan dalam Pasal 111 jauh lebih berat dibandingkan dengan sanksi pidana dalam Pasal 112 UUPPLH. Hal ini menimbulkan pertanyaan besar, mengapa demikian. Padahal kalau ditinjau dari segi beratnya tingkat pelanggaran dan rumitnya pembuktian di Pengadilan, seharusnya (secara ius constituendum) sanksi yang ada dalam Pasal 112 UUPPLH lebih berat dibandingkan dengan sanksi yang ada dalam Pasal 111 UUPPLH.

\section{PENUTUP \\ Kesimpulan}

Berdasarkan uraian dalam bab pembahasan maka dapat dikemukakan beberapa kesimpulan sebagai berikut:

Pertama, Persyaratan izin lingkungan di atur dalam Pasal 22 UUPPLH. Di mana syaratnya harus memiliki AMDAL, yang kemudian disusun menjadi dokumen AMDAL. Dokumen AMDAL harus memuat antara lain: 1. Pengkajian mengenai dampak rencana usaha dan/atau kegiatan; 2. Evaluasi kegiatan di sekitar lokasi rencana usaha dan/atau kegiatan; 3. Saran masukan serta tanggapan masyarakat terhadap rencana usaha dan/atau kegiatan; 4. Prakiraan terhadap besaran dampak serta sifat penting dampak yang terjadi jika rencana usaha dan/atau kegiatan tersebut dilaksanakan; 5. Evaluasi secara holistik terhadap dampak yang terjadi untuk menentukan kelayakan atau ketidaklayakan lingkungan hidup ; dan 6. Rencana pengelolaan dan pemantauan lingkungan hidup.

Prosedur penerbitan izin lingkungan diatur dalam Pasal 36 UUPPLH yang menjelaskan bahwa 
setiap usaha dan/atau kegiatan yang wajib memiliki AMDAL atau UKL-UPL wajib memiliki izin lingkungan. Kemudian dari izin lingkungan tersebut diterbitkan berdasarkan keputusan kelayakan lingkungan hidup atau rekomendasi UKL-UPL. Selanjutnya, izin lingkungan tersebut wajib mencantumkan persyaratan yang dimuat dalam keputusan kelayakan lingkungan hidup atau rekomendasi UKL-UPL. Kemudian, izin tersebut diterbitkan oleh Menteri, Gubernur, atau Bupati/ Walikota sesuai dengan kewenangannya.

Kedua, Akibat hukum bagi pejabat yang tidak mengindahkan prosedur dan persyaratan penerbitan izin lingkungan akan dikenakan sanksi sesuai dengan Pasal 111 dan Pasal 112 UUPPLH. Dimana bentuk sanksi yang dirumuskan adalah pidana penjara dan pidana denda. Akan tetapi, ada 2 (dua) perbedaan dalam sanksi yang di atur dalam Pasal 111 dan 112 UUPPLH. Sanksi dalam Pasal 111 dikenakan sanksi pidana penjara dan denda. Sedangkan dalam Pasal 112, diharuskan memilih salah satu (antara sanksi penjara atau denda). Berarti, sanksi dalam Pasal 111 lebih berat ancamannya dibandingkan sanksi dalam Pasal 112 UUPPLH.

\section{Rekomendasi}

Instansi atau pejabat yang berwenang untuk menerbitkan izin lingkungan harus menjelaskan secara terbuka tentang prosedur dan persyaratan izin lingkungan. Hal yang demikian akan memberikan informasi secara dini bagi masyarakat yang membutuhkannya.

Bahwa pejabat dalam melaksanakan pelayanan perizinan lingkungan harus berpedoman pada prosedur dan persyaratan yang telah ditentukan. Pelayanan yang taat prosedur akan memberikan kepastian dan preseden yang positif bagi masyarakat luas.

\section{DAFTAR PUSTAKA}

\section{Buku:}

Basuki, Ahmad. 2011. Pertanggungan Jawab Pidana Pejabat atas Tindakan Mal-Administrasi dalam Penerbitan Izin di Bidang Lingkungan. Jurnal Perspektif Vol. XVI No. 4, FH UWKS.

Fandeli, Ch. 2004. Analisis Mengenai Dampak Lingkungan Prinsip Dasar dalam Pembangunan. Yogyakarta: Liberty.
Hadjon, Philipus M. 2011. Hukum Administrasi dan Tindak Pidana Korupsi. Yogyakarta: Gadjah Mada University Press.

Harun, M. Husein. 1992. Berbagai Aspek Hukum Lingkungan. Jakarta: Bumi Aksara.

Helmi. 2012. Hukum Perizinan Lingkungan Hidup. Jakarta: Sinar Grafika.

HR Ridwan. 2007. Hukum Administrasi Negara. Jakarta: Rajagrafindo Persada.

Muladi dan Barda Nawawi Arief. 2010 Bunga Rampai Hukum Pidana. Bandung: Alumni.

Rangkuti, Siti Sundari. 2000. Hukum Lingkungan dan Kebijaksanaan Lingkungan Nasional. Surabaya: Airlangga University Press.

Silalahi, M. Daud. 1995. Amdal dalam Sistem Hukum Lingkungan. Jakarta: Grafindo.

Sudarto. 1990. Hukum Pidana I Cetakan ke II. Yayasan Sudarto. Semarang: Fakultas Hukum Universitas Diponegoro.

Suparni, Ninik. 1994. Pelestarian, Pengelolaan, Penegakan Hukum Lingkungan di Indonesia. Jakarta: Sinar Grafika.

Sutedi, Adrian. 2010. Hukum Perizinan dalam Sektor Pelayanan Publik. Jakarta: Sinar Grafika.

Utrecht. 1963. Pengantar Hukum Administrasi Indonesia. Jakarta: Ikhtiar.

Weda, Kupita. 2007. Peranan Komisi Ombudsman Nasional dalam Penegakan Hukum dan Pelayanan Umum Pemerintah (Eksistensi Ombudsman dalam Lintasan Sejarah). Purwokerto: Universitas Jenderal Soedirman.

\section{Peraturan Perundang-undangan:}

Undang-Undang Nomor 4 Tahun 1982 tentang Lingkungan Hidup

Undang-Undang Nomor 5 Tahun 1986 tentang Pengadilan Tata Usaha Negara.

Undang-Undang Nomor 23 Tahun 1997 tentang Pengelolaan Lingkungan Hidup.

Undang-Undang Nomor 37 Tahun 2008 tentang Ombudsman Republik Indonesia.

Undang-Undang Nomor 32 Tahun 2009 tentang Perlindungan dan Pengelolaan Lingkungan Hidup.

Peraturan Pemerintah Nomor 27 Tahun 2012 tentang Izin Lingkungan. 